\title{
Peacebuilding, Democratization, and Political Reconciliation in Cambodia
}

\author{
Raimund Weiß
}

\begin{abstract}
This research article explains why Cambodia's dual transition of peacebuilding and democratization after the civil war led to peace but not democracy. The research finds that democratization often threatened peacebuilding in Cambodia. Particularly elections led to political instability, mass protests, and renewed violence, and thus also blocked reforms to democratize Cambodia's government institutions. By applying the war-to-democracy transition theory and theories of political reconciliation to Cambodia's dual transition, the following research article finds that a lack of political reconciliation between Cambodia's former civil war parties is the main reason why the dual transition failed. This article argues that peace-building and democratization are only complementary processes in post-civil war states when preceded by political reconciliation between the former civil war parties.
\end{abstract}

Keywords Cambodia, dual transition, peacebuilding, democratization, war-to-democracy transition theory

\section{Introduction}

The year 2020 marks almost thirty years of peacebuilding in Cambodia. The country appears to have overcome the violence and destruction of two civil wars and the totalitarian Pol Pot regime. Cambodia experiences the longest-lasting peace since gaining independence from France in 1953. But despite this progress, peacebuilding in Cambodia did not lead to the consolidation of liberal multiparty democracy as foreseen in the Paris Peace Accords. In July 2018, Cambodia held the sixth national election since the end of the civil war. The incumbent Cambodian People's Party (CPP) under Prime Minister Hun Sen won for the first time all 125 seats of Cambodia's National Assembly. This became possible because just nine months before the election, the Cambodian Supreme Court had dissolved the Cambodian National Rescue Party (CNRP), the largest opposition party and only viable challenger of the CPP. The CPP faced for the first time the 
risk of electoral defeat and government change in the preceding 2013 national election, wherein the CNRP won fifty-five parliamentary seats and also made electoral gains in the 2017 commune election. The dissolution of the CNRP averted a possible electoral defeat of the CPP. The government argued that the dissolution of the CRNP saved Cambodia's peace even though democratization came to an abrupt standstill.

This political development raises the question of why peacebuilding and democratization have not been complementary processes in Cambodia. Although various scholars conducted research on peacebuilding and democratization in Cambodia, none explicitly examined how the processes of peacebuilding and democratization relate to each other in the specific case of Cambodia. Research has been conducted on peacebuilding and democratization in Cambodia on the following questions: Can Cambodia achieve peace through retributive justice (Peou 2017)? What are the potentials and limitations of liberal peacebuilding defined as a liberal project of democratization and marketization in Cambodia (Peou 2014; Croissant 2008)? Is Cambodia developing towards a democratic political system (Un 2005, 2006; Beresford 2005)? Lastly, is Cambodia an authoritarian political system (Springer 2010; Chambers 2015; Strangio 2014; Sullivan 2016; Noren-Nilsson 2016)?

This article extends the existing research. It provides an analysis of how the processes of peacebuilding and democratization relate to each other in Cambodia and explain why Cambodia's dual transition of peacebuilding and democratization led to peace but not democracy. To achieve these research objectives, the article applies the war-to-democracy transition theory and theories of political reconciliation, which will be introduced in the next section. This article applies the research methods of process-tracing and discourse analysis for the collection and analysis of data. Process-tracing in social science research is defined as "a method to identify the causal chain and causal mechanisms that connect hypothesized causes and outcomes" (Halperin and Heath 2012, 89). Discourse analysis is defined as a method that "assumes that people act on the basis of beliefs, values, or ideology that give meaning to their actions" (ibid., 310). Process-tracing enabled the author to trace back Cambodia's dual transition of peacebuilding and democratization since the end of the civil war. Discourse analysis, in turn, provided a framework for examining whether or not Cambodia’s political elites have politically reconciled.

\section{Analytic Framework of the Relationship between Democratization, Peacebuilding, and Political Reconciliation}

Democratization is a transitional process from authoritarian to democratic rule. Peacebuilding is a transitional process from violent intra- or inter-state 
conflict to peace. Both processes can complement each other but often also lead to dilemmas. The war-to-democracy transition theory argues that "...peace and democracy do not always move forward hand in hand: sometimes advances in democratization threaten peace and the compromises necessary for peace restrict or defer democratization" (Jarstad 2008, 17). The war-to-democracy transition theory names three dilemmas that can challenge dual transitions of peacebuilding and democratization: (1) horizontal dilemma, (2) vertical dilemma, and (3) temporal dilemma.

The "horizontal dilemma" (ibid., 22) is explained as the decision-making dilemma about whom to include in the peacebuilding and democratization process. It might be necessary to be as inclusive as possible to strengthen democratization. But broad inclusion of various stakeholders might make compromise difficult and imperil the peacebuilding process. Also, stakeholders, who contradict democratization, might need to be included. For example, when stakeholders who have committed severe human rights violations are included, this can threaten the overall democratization process. The "vertical dilemma" (ibid., 23) is explained as the dilemma of the difficult choice that political elites have to make between the efficiency and legitimacy of the policy decisionmaking process. Democratization requires a people-centered policy decisionmaking process. Yet, a people-centered approach may make policy decisionmaking inefficient eventually jeopardizing peacebuilding whereas elite-centered policy decision-making is more efficient but may contradict democratization. The "temporal dilemma" (ibid., 26) is explained as the decision-making dilemma about how much democratization in a post-civil war context is possible in the short-term without risking renewed violence. Research on democratization and peacebuilding has found that "democratization increases the probability of civil war onset over several years" (Cederman et al. 2010, 379). One of the reasons for this negative correlation is that "democratization implies mass mobilization and that the latter may trigger violence if the political institutions are not prepared to accommodate this level of participation" (Samuel Huntington quoted from ibid., 378).

Theories of political reconciliation explain the importance of political reconciliation in dual transitions of peacebuilding and democratization. They emphasize that political reconciliation is a building block of the peacebuilding process. Political reconciliation is distinguishable from other reconciliation processes because political reconciliation is "not dependent on the kind of intimacy that religions and some forms of individual reconciliation may demand. Rather, statecraft and politics require peaceful coexistence ... forgiveness may come later, after the creation of confidence and the building of trust" (VillaVicencio 2004, 5-6). Political reconciliation is a process of rebuilding political relations between former adversaries. Political reconciliation theory also explains that democratization does not only depend on pluralism and political 
competition. It also depends on "an underlying set of agreements, both legal and tacit, on a common 'vision' [...] on the definition of the national community, on the 'rules of the game', and on the way in which leaders communicate and relate to one another. In short, democracy depends as much upon competition as on cooperation" (Wolpe and McDonald 2008, 139).

Based on the propositions of the war-to-democracy transition theory and theories of political reconciliation, the research article presents the hypothesis that peacebuilding and democratization can only complement each other when preceded by political reconciliation. Cambodia as a post-civil war state provides a representative case study to test this hypothesis. Potentially, the study provides the foundation for a new transition theory of peacebuilding and democratization that incorporates political reconciliation as a central analytical concept.

\section{Peace through Power-Sharing}

On October 23, 1991, the Cambodian civil war parties signed the Paris Peace Accords that ended Cambodia's two decades of violence. They agreed to end the civil war with a dual transition of peacebuilding and democratization, stating that Cambodia should achieve a lasting peace with democratic elections and a new liberal democratic constitution. In May 1993, Cambodians voted under the supervision of the United Nations Transitional Authority of Cambodia (UNTAC) in the first democratic election since the end of the civil war. The election was a success as they legitimized the former Cambodian civil war parties (Frost 1994), which included parties supported by both the Eastern and Western Bloc.

During the civil war, the political legitimacy of the civil war parties was highly contested. The communist Eastern Bloc led by the Soviet Union recognized the Kampuchea People's Revolutionary Party (KPRP) as the sole legitimate party and government of Cambodia. In January 1979, the KPRP overthrew the totalitarian Pol Pot regime with support from Vietnam. Under Vietnam's supervision, the KPRP developed Cambodia into a Leninist Marxist one-party state named the People's Republic of Kampuchea (PRK). From 1985 on, Minister-President Hun Sen led the PRK (Chhim 2000; Vickery 1994).

The Western Bloc led by the United States, the Association of Southeast Asian Nations' member states and China did not recognize the PRK government. They supported the Cambodian exile coalition government of late King Norodom Sihanouk. The exile government was formed in 1982 and named the Coalition Government of Democratic Kampuchea. It included the monarchic party National Front for an Independent, Neutral, Peaceful and Cooperative Cambodia (FUNCINPEC), the republican party Khmer People National Liberation Front (KPNLF) and the Party of Democratic Kampuchea (PDK). The latter was the successor party of the Communist Party of Kampuchea, which is also known 
under the name "Khmer Rouge." The exile coalition government demanded an end to Vietnam's occupation of Cambodia, and to conduct democratic elections under the supervision of the United Nations (UN) (Becker 1998).

The first democratic election legitimized Cambodia's civil war parties (except for the PDK) but did not result in a democratic government formation. Contrary to the expectations, not the successor party of the KPRP, the Cambodian People's Party (CPP) but the monarchic FUNCINPEC won the election. The party gained a simple majority of fifty-eight seats of a total of at this time of 120 National Assembly seats. The CPP gained fifty-one National Assembly seats and the successor party of the KPNLF, the Buddhist Liberal Democratic Party (BLDP) won ten seats. The CPP refused to accept the election results, alleged irregularities and threatened the secession of three provinces in eastern Cambodia. A major political crisis that could have escalated to a new civil war was only averted after mediation of the re-crowned late King Norodom Sihanouk. The former civil war parties agreed to a power-sharing formula that included all elected political parties in an all-party coalition government under the leadership of a two prime minister system. The first Prime Minister was Prince Norodom Ranariddh, a son of late King Norodom Sihanouk and FUNCINPEC President. The second Prime Minister was Hun Sen, the former Minister-President of the PRK. In September 1993, a new constitution was adopted by the National Assembly. Cambodia was declared a constitutional monarchy based on the principles of liberal democracy and named the Kingdom of Cambodia (Menzel 2016).

The formation of an all-party coalition government saved peacebuilding but contradicted democratization. According to the election results, the CPP should have become a junior coalition partner in a government led by the majority party FUNCINPEC under the leadership of only one Prime Minister, Prince Norodom Ranariddh. The BLDP should have become the parliamentary opposition. With the formation of an all-party-government, the CPP had now gained equal powers to FUNCINPEC despite having obtained fewer seats in the National Assembly. Moreover, with the inclusion of the BLDP in the coalition government, no opposition party was represented in the first post-civil war National Assembly (Ashley 1998; Lizee 2000).

\section{Peace through Military Force}

Cambodia's peacebuilding process was also put at risk because of the PDK. The PDK who first had signed the Paris Peace Accords boycotted the peace process and the UN-supervised 1993 national elections. The PDK refused to order their forces to go in a cantonment for disarmament. PDK forces continued guerrilla warfare against the CPP. Additionally, the PDK alleged that Vietnamese troops were still stationed in Cambodia to support the CPP; however, UNTAC found no 
proof for the allegations (Hazdra 1997). The PDK guerrilla warfare also continued after the election. In 1994, the Cambodian government outlawed members of the PDK and sought a military solution but this policy did not end the violence. Cambodia's government saw no other choice than to pursue an amnesty policy for the PDK. The PDK forces should be either integrated back into civilian life or into the newly formed Royal Cambodian Armed Forces (RCAF) (Linton 2004). The amnesty policy proved successful. Two-thirds of the PDK forces changed in 1996 to the government side. Only a few PDK splinter groups continued the guerrilla warfare.

Yet, the integration of PDK forces into the RCAF altered the military balance between FUNCINPEC and CPP within the RCAF. During the civil war, FUNCINPEC allied with the PDK while the CPP was the PDK's fiercest adversary. FUNCINPEC and CPP now competed for control of the PDK forces in the RCAF (Peou 1998; Springer 2010). The amnesty policy also contradicted democratization considering the crimes PDK members had committed during their rule. At the same time, political tensions in the all-party coalition government were rising. FUNCINPEC claimed to be unable to govern within a CPP dominated state administration. In 1997, FUNCINPEC threatened to leave the coalition government, to dissolve the National Assembly, and to hold an early national election. FUNCINPEC also formed an extra-parliamentary alliance with the BLDP and a new opposition party, the Sam Rainsy Party (SRP). FUNCINPEC had expelled Sam Rainsy from the government and party after he accused the FUNCINPEC and CPP of corruption. The extra-parliamentary alliance was named the National United Front (Peou 1998) and aimed to mobilize political support for the opposition against the CPP and the second Prime Minister Hun Sen.

By July 1997, the CPP perceived that the military balance within the RCAF had shifted in favor of FUNCINPEC (Cambodian Ministry of Foreign Affairs and International Cooperation 1997; Mehta 1999). It followed a military showdown. Military forces loyal to CPP and FUNCINPEC clashed in north-western Cambodia, and later in the capital Phnom Penh. Fighting continued until August when CPP forces gained the upper hand, forcing the FUNCINPEC to capitulate. The CPP defended the violence, claiming that Prime Minister Prince Norodom Ranariddh had planned the assassination of the second Prime Minister Hun Sen (Cambodian Ministry of Foreign Affairs and International Cooperation 1997). Prince Norodom Ranariddh denied the allegations. He accused the CPP of staging a coup. Despite both sides' claims, evidence suggests responsibility for the July-Crisis is on both sides (Peou 1998; Vickery 1997).

The July Crisis was a large setback for the peacebuilding and democratization process. Yet, the outcome of the crisis was the monopolization of the legitimate use of physical force by the state which now was under the sole control of the $\mathrm{CPP}$. This brought the civil war to a conclusive end. Also, the last PKD splinter 
groups changed to the government side in 1998. Prince Norodom Ranariddh who had fled the country before the July-Crisis was first prosecuted by Cambodian courts but later amnestied by late King Norodom Sihanouk. The amnesty paved the way for the second national election in July 1998 (ICG 1998).

\section{Peace through Limited Democratization}

Reforms should have transformed Cambodia's political system into a liberal multiparty democracy. Such a democratic system would have included the conduct of regular universal elections on national and local levels and indirect elections for province and district councils and the Senate, which was formed in 1999 as the second chamber of Cambodia's parliament. A new law on political parties to develop a multiparty system was adopted in October 1997. Reforms of the legislative and judiciary should have strengthened oversight powers over the executive (Bhagat 2015). But contrary to the expectation that democratization would complement peacebuilding, reforms to democratize Cambodia's political system continued to lead to political instability and threatened peacebuilding. In particular national elections had politically destabilizing effects.

Each national election in Cambodia since 1993 caused a severe post-election political crisis. In 1993, the government party CPP refused to recognize the election results. In 1998, the second post-election political crisis occurred as the opposition refused to recognize the election results. The 1998 national elections were conducted by Cambodian state authorities without the supervision of the United Nations. Different from the 1993 national elections results, the CPP won in 1998 with an absolute majority controlling sixty-four seats of the now total 123 National Assembly seats. FUNCINPEC gained forty-three seats while the BLDP did not secure enough votes to obtain a seat. Instead, the newly found opposition party SRP won fifteen seats in its first election contest. For the first time since the end of the civil war, an opposition party was represented in the Cambodian parliament. Despite this democratic progress, FUNCINPEC and SRP contested the results. They alleged irregularities and organized mass protests that led to a three-month delay in the government formation and the outbreak of violent incidents (ICG 1998; Hughes and Real 2000). The national elections in 2003 and 2013 followed a similar pattern. Except for the 2008 national elections, when the CPP formed a single-party government after the party had won twothirds of the 123 National Assembly seats, the opposition won in 2003 and 2013 enough parliamentary seats to contest the election results on the streets and delay government formations. In a similar manner to the aftermath of the 1998 national elections, the opposition organized mass protests and National Assembly boycotts that led to violent incidents mainly committed by government security forces and caused a one-year delay of the government formation in 2003 and 2013 
(COMFREL 2003, 2013). Only after protracted negotiations between opposition and government was it possible to diffuse the post-election political crisis. In 2003, late King Norodom Sihanouk mediated a resolution of the electoral dispute (Weiß 2004).

The opposition claimed that the CPP had obtained election victories since 1998 through the means of intimidation and threats, unequal access to media, a partial election administration, the misuse of state resources for campaign purposes, the employment of civil servants and military personnel for election campaigns, vote-buying and the disenfranchisement of voters (Croissant 2016). Opposition leader Sam Rainsy claimed in his autobiography from 2008, that the CPP under Prime Minister Hun Sen has manipulated national elections with "Khmer Rouge politics" (quoted from Noren-Nilsson 2016, 143). According to him, the CPP applied a "3Ks formula” which translates into 'khlach' (fear), 'khlean' (hunger) and 'khlov' (ignorance) and means that the CPP manipulated elections with intimidation, vote-buying and propaganda (ibid., 143). The government party CPP countered the opposition allegations with lawsuits, arrests, imprisonments, and convictions of opposition members and supporters (Springer 2010). The allegations of the opposition were partly supported by national and international election observers. They criticized that Cambodian elections never have been fully free and fair because of the above-listed reasons even if they did not find a systematic pattern of irregularities that would have allowed them to invalidate any of the past national election results (COMFREL 1998, 2003, 2008, 2013).

In this context, it is notable that the constitutional requirement of a twothirds majority vote to form governments backlashed in Cambodia's peacebuilding process. The rule was meant to facilitate political reconciliation among the former civil war parties. But it also allowed FUNCINPEC to ally with the opposition, dispute election results, and block government formations. Yet in 2006, the opposition turned against FUNCINPEC. The SRP supported a parliamentary vote of the CPP to change the two-thirds rule to an absolute majority rule. From then on, the CPP no longer needed to form coalition governments with FUNCINPEC. Following the constitutional change, FUNCINPEC became internally divided and lost political support. In the 2008 elections, the party only won two seats. In the 2013 national elections, the party failed to win a single seat. Most of the FUNCIPEC votes appear to have moved to the opposition party SRP and the HRP, which was formed in 2007 by Kem Sokha, a former FUNCINPEC member and human rights activist. In the 2008 national elections, the SRP won twenty-six seats and the HRP three seats. When SRP and HRP merged in 2012, to become the Cambodian National Rescue Party (CNRP), the opposition succeeded to win fifty-five seats in the 2013 national elections. Despite this, the CPP was able to secure sixty-eight seats once again obtaining an absolute majority of National Assembly seats (Hughes 2015).

The recurring post-election political crisis after every national election also 
diminished opportunities to reform and democratize Cambodia's legislative and judiciary. The legislative was often dysfunctional because of the political tensions between the opposition and government. The CPP often responded to opposition attacks with non-cooperation and the exclusion of opposition members from the parliamentary working commissions. The opposition was also constantly outvoted by the CPP in plenary sessions because the party had secured a majority of the National Assembly and Senate seats in all national elections since 1998 (COMFREL 2012, 2013, 2014, 2015, 2016, 2017).

Similarly constrained were reforms to strengthen the independence of the judiciary. Since 1998, no other political party than the CPP had been able to secure majorities in Cambodia's main judicial bodies. In the Constitutional Council, the CPP has five of the total nine council seats. The CPP also holds a majority in the Supreme Council of Magistracy. This judicial body promotes, appoints, and disciplines judges and prosecutors and is presided over by the CPP-led Ministry of Justice. The independence of Cambodia's judiciary has been consecutively questioned by the opposition, civil society organizations, and scholars (Un 2009; IBAHRI 2015; Strangio 2014).

Only in July 2014 after the CNRP agreed to accept the election results and to share power with the CPP in the National Assembly could democratization have made significant progress. Opposition leader Sam Rainsy was elected as a parliamentary minority speaker. Deputy opposition leader Kem Sokha was elected as the first National Assembly Vice-President. The CPP and CNRP also shared equally the chairs of the ten parliamentary working commissions of the National Assembly. For the first time, the legislative appeared to have an effective oversight power. The legislative did question ministers, investigated corruption cases, and conducted parliamentary workshops and consultations on various policies and laws (COMFREL 2015).

However, the achieved democratic progress proved to be short-lived. The CNRP and CPP would ultimately fail to politically reconcile, a point which is explained further in the next section. In 2017, Cambodia's Supreme Court dissolved the CNRP on treason charges. The CNRP is alleged to have plotted with the United States to overthrow the government (COMFREL 2017). Since the 2018 national elections, the CPP holds now all 125 National Assembly seats. Cambodia's parliament today is de facto though not de jure a single party two-chamber parliament (Baliga and Sokhean 2018).

The dissolution of the CNRP also negatively affected efforts to democratize Cambodian local politics. In the 2017 commune elections, the opposition won for the first time 489 commune councils although the CPP secured a majority with 1,156 commune councils (COMFREL 2017). Other political parties than the CPP had until 2017 not been able to build a local political power base in Cambodia. The CPP held majorities in most of a total of 1,621 commune councils since 2002. In the first commune elections in 2002, the CPP won 1,598 commune councils. 
FUNCINPEC won only ten and the SRP thirteen commune councils. In the 2007 commune elections, the CPP won 1,591 commune councils. FUNCINPEC won only two and the SRP twenty-eight commune councils. In the 2012 commune elections, the CPP won 1,592 commune councils. FUNCINPEC won only one and SRP twenty-two commune councils (COMFREL 2002, 2007, 2012).

Had the CNRP not been dissolved in November 2017, the opposition could have also won more seats in the Senate elections that were held in February 2018. Fifty-eight of a total of sixty-two Senate seats are indirectly elected by the commune councilors. With the dissolution of the CNRP, the CNRP commune council seats were allocated to other political parties. The CPP with 4,548 seats took a majority of the opposition seats. FUNCINPEC obtained 239 seats. Other seats were given to the little-known Khmer Nationality Party (201 seats), the Cambodian Nationality Party (ten seats), the Cambodian Youth Party (three seats) and the Cambodia Indigenous People Democracy Party (three seats). Except for FUNCINPEC, these political parties had not won majorities in any of the 1,621 commune councils since 2002. Because of the dissolution of the CNRP, the CPP won in the 2018 indirect elections of the Senate all fifty-eight Senate seats (Kijewski and Chakrya 2017).

\section{Peace without Political Reconciliation}

Political reconciliation is a difficult challenge for Cambodia's political elites. Two civil wars (1970-1975 and 1979-1991), the Pol Pot regime (1975-1979) and violent incidents during peacebuilding in the 1990s led to trauma, societal fragmentation, political divisions, grievances, mistrust, and political intolerance. According to the Cambodian peace researcher Soth Plai Ngarm $(2017,34)$, Cambodia is "in the circle of the past, even though a generation is almost over." An estimated 1.6 million people died during the totalitarian rule of Pol Pot (Kiernan 2002). During the first civil war (1970-1975) an estimated 310,000 people were killed (Sliwinski 1995). During the second civil war (1979-1991) an estimated 55,000 Vietnamese soldiers were killed and an equal number were wounded (Reaves 1988). The number of Cambodian deaths remains unknown but it is estimated that 750,000 Cambodians fled from their home country after the fall of the Pol Pot regime. From those, an estimated 200,000 returned to Cambodia in the 1980s and 250,000 resettled in other countries (mainly to the United States, Australia, and France). Three hundred thousand Cambodians lived during the 1980s in refugee camps along the Thai-Cambodian border. It was not until 1992-1993 that they were repatriated by UNTAC (Ablin and Hood 1990).

The Cambodian diaspora often supported the monarchic FUNCINPEC and the republican KPNLF during the second civil war. That support continued in post-civil war Cambodia but shifted in the past decade to the opposition 
parties SRP and HRP, and later on to the CNRP. Cambodians who stayed in the country during the second civil war often supported the KPRP. That support shifted in post-civil war Cambodia to the CPP. The political divisions of the past civil wars appear to have left Cambodia's political elites "an unfinished imagined community" (Noren-Nilsson 2016, 2).

This is also reflected in the divisive political discourses that Cambodian political elites have constructed in the past two decades over the meaning of the past civil wars. The opposition portrays the CPP leadership as former Khmer Rouge members who were involved in crimes during the Pol Pot regime and as an illegitimate political force that has only come to power because of Vietnam's support and occupation of Cambodia. In contrast to the CPP, the opposition party portrays themselves as the genuine savior of the Cambodian nation who has fought liberation wars against the Khmer Rouge and Vietnam.

Anti-Vietnamese political campaigns, particularly during national elections, reinforced this negative image of the CPP leadership in the Cambodian public. For example, opposition leader Sam Rainsy claimed during a campaign speech for the 2013 national elections: "We are full. We have been eating Vietnamese sour soup for 30 years. This time we need to eat a traditional Khmer soup" (quoted from Narin and Meyn 2013). Sam Rainsy also claimed that Cambodia has lost land to companies and illegal immigrants from Vietnam, promising before an audience that when he comes to power: "We have to kick the Vietnamese out and will collect our property back" (ibid.). Likewise, deputy opposition leader Kem Sokha claimed in a campaign speech that Vietnam has fabricated the former Khmer Rouge security prison S-21 to justify Vietnam's invasion and occupation of Cambodia (Eang and Zsombor 2013). In S-21 (also known under the name Tuol Sleng) an estimated 14,000 people had been tortured and killed by the Khmer Rouge between 1975 and 1979. To publicly demonstrate the nationalistic anti-Vietnamese stance of the opposition, CNRP members also joined in 2014, the 35th-anniversary celebration of the former republican civil war party KPNLF. The latter has been known for its fierce anti-Vietnamese posture during the civil war (Willemyns 2014a).

The CPP leadership counters the opposition with their narratives. The party claims that not the opposition but the CPP is the genuine savior of the Cambodian nation because only under CPP leadership, has Cambodia overcome the destructions of the past civil wars and the Pol Pot regime. The opposition has been accused to have lived abroad and not helped in the reconstruction of Cambodia. Leading CPP members, including Hun Sen, Chea Sim, Heng Samrin, and Hor Namhong among others, see themselves as Khmer Rouge victims who defected from the totalitarian Pol Pot regime and saved Cambodia with the help of Vietnam. The CPP leadership also praises its role for preventing the Khmer Rouge from returning to power whereas the opposition is criticized for its alliance with the Khmer Rouge during the second civil war. The opposition is accused of 
having provided in the 1980s legitimacy and international support for the Khmer Rouge despite their horrendous crimes. That also could have enabled the Khmer Rouge under Pol Pot to return to power in the 1980s, had the CPP and Vietnam not prevented it (Mehta 1999).

Political reconciliation between opposition and government is also a difficult challenge because of allegations by the opposition that the CPP leadership has been involved in crimes after the civil war. The opposition commemorates to this day a grenade attack on one of its peaceful demonstrations in Phnom Penh in March 1997. The grenade attack killed sixteen people and injured one hundred others. Opposition leader Sam Rainsy barely escaped alive. After the attack, the opposition alleged that the bodyguard unit of Prime Minister Hun Sen had been involved in the attack (Strangio 2014; UNHCHR 1998; Meas 2010). In 2011, the opposition party SRP announced during a party convention that they would file "criminal lawsuits against those current leaders responsible for crimes against humanity..., war crimes ... and other heinous crimes ... before international courts and independent courts in democratic countries" (SRP 2011). Furthermore, opposition leader Sam Rainsy alleged that Bun Rany, the wife of Prime Minister Hun Sen "has masterminded...the assassination of Ms. Piseth Pilika, a renowned Cambodian artist." The opposition leader also claimed that the former Minister of Foreign Affairs Hor Namhong was in charge of a Khmer Rouge prison camp (COMFREL 2012, 22).

The CPP leadership responded to these allegations with threats and lawsuits. For example, Prime Minister Hun Sen was quoted by the media, saying that he wants "not just to weaken the opposition, but to make it die" (quoted from Fitzpatrick 2011). He also has been reported saying that the SRP is acting like the murderous Pol Pot regime (Vong 2011). The Prime Minister also warned in public speeches of the possibility of war should the opposition win the next national elections (Kuch 2015b). In response to Kem Sokha's claim that S-21 has been fabricated by Vietnam, the Cambodian National Assembly approved a new law that prosecutes individuals who deny that the Khmer Rouge committed crimes against humanity (Meas 2013).

First attempts by the government and opposition to politically reconcile were made after the July 2014 agreement that led to power-sharing in the National Assembly. The government and opposition proclaimed to develop a "culture of dialogue" and committed to refraining from public insults, defamations, threats, and intimidation against each other (COMFREL 2015). The government and opposition also approved a code of conduct that prohibited the use of certain words and phrases. For example, it has been prohibited to use the phrase "Vietnamese head with a Cambodian body," which was coined by the Khmer Rouge (see Kiernan 2002, 407). Furthermore, it was prohibited to use the phrases "Communist dictator," "Vietnamese puppet," "person who sells their nation," and "leader of the thieves." Also, the use of threatening and intimidating words like 
"arrest and jail" and "war will occur" were prohibited (quoted from Kuch 2015a).

In August 2014, Prime Minister Hun Sen emphasized in a public speech the importance of the culture of dialogue: "Let us stop the culture of coloring one another. The policy of fish eating (sic) ants and ants eating fish when the flood recedes should stop" (CNV 2014a). Opposition leader Sam Rainsy responded that "the culture is what Hun Sen has spoken about, that 'when the waters flood, the fish eats the ants, and when the waters recede, the ants eat the fish.' We are in this culture of revenge, that any party that comes to power will eliminate the one that was previously in power. The background of our approach now is to create a new culture and to make the people and the CPP less afraid of any regime change, that it will not bring bloodshed and revenge" (quoted from Willemyns 2014b). In December 2014, Hun Sen reinstated the importance of developing a culture of dialogue in a public speech: "Each individual, family and community and a country must make further efforts-those inside or outside the Royal Government-to create a culture of dialogue" (CNV 2014b).

However, these first political reconciliation attempts failed in January 2015 when the opposition launched a new anti-Hun Sen campaign. Deputy opposition leader Kem Sokha claimed in a public speech that "there are no leaders, regimes, era, or generations that have destroyed the Khmer's forests, land, and natural resources more than the regime of Prime Minister Hun Sen. Our goal is the same, to change today's leaders. In the world, the leaders who cling to power for a long time have not been good or honest to the nation and their people, and the longest-serving leaders in the world are dictatorial and corrupt people" (Kem Sokha quoted from Dara 2015). The opposition also orchestrated a new nationalistic anti-Vietnamese campaign to discredit the CPP government. The CNRP demanded renegotiations of current border treaties with Vietnam $(\mathrm{Ou}$ 2016). The party claimed that the CPP government had used incorrect maps to demarcate the borders and circulated those maps via social media. To gain public momentum, the CNRP organized marches to alleged disputed border areas. In one instance, $250 \mathrm{CNRP}$ activists tried to push through alleged disputed territory controlled by Vietnam. This led to a brawl with Vietnamese border authorities. Seven Vietnamese were injured. Vietnam's government denounced the CNRP activists to be "extremists" (Meas and Shaun 2015).

The CPP government responded to the new opposition attacks with threats to end the culture of dialogue. Prime Minister Hun Sen called Sam Rainsy "a leader of thieves" and "a liar" and alleged the opposition has planned an "orange revolution" (quoted from Kuch 2015b). CPP supporters organized a rally in front of the National Assembly demanding the resignation of Kem Sokha from his position as First National Assembly Vice-President. After the protest, two CNRP parliamentarians were beaten up by members of the bodyguard unit of Prime Minister Hun Sen. What followed was defamation lawsuits, arrests, convictions, and imprisonments of opposition parliamentarians, opposition 
members and supporters (Chakrya et al. 2015). Also, senior officials of the Royal Cambodian Armed forces intervened in the conflicts between government and opposition despite that laws oblige RCAF members to remain politically neutral (ibid.). Defence Minister Tea Banh called for the elimination of "people, who have the wrong kind of mentality" (quoted from Baliga et al. 2016). Kun Kim, RCAF Deputy Commander announced that his troops would arrest the opposition leaders when they receive an order. A spokesman of the Prime Minister bodyguard unit declared: "We will absolutely not allow people who want to trigger a color revolution and some ill-intentioned people who want to destroy this peace-we will not let them do it" (quoted from ibid.; Dara 2016). By the end of 2017, relations between the opposition party CNRP and government party CPP had fully deteriorated. Acting on a government request, the Cambodian Supreme Court dissolved the CNRP on allegations of fomenting a revolution and conspiring with the United States to overthrow the CPP government. New lawsuits and arrests followed, including the imprisonment of Kem Sokha who later was put under house arrest. Other opposition members and parliamentarians fled the country, including opposition leader Sam Rainsy. The CNRP denies the allegations (Sokhean et al. 2017).

\section{Conclusion}

The study proves that peacebuilding and democratization have not been complementary processes in Cambodia because political reconciliation between the former civil war parties has continuously failed. The findings support the hypothesis of this study that democratization and peacebuilding can only be complementary processes when preceded by political reconciliation. Providing that this was not the case in Cambodia, democratization has more often threatened than strengthened peacebuilding. Because of the absence of political reconciliation, the Cambodian government had to prioritize peacebuilding over democratization. Peacebuilding only succeeded through power-sharing, military force, and limited democratization. Despite this setback for democratization, Cambodia succeeded in building and maintaining peace since 1998 .

The contradictions in Cambodia's dual transition additionally confirm the propositions of the war-to-democracy transition theory. Cambodia's dual transition faced a horizontal, vertical, and temporal dilemma. The horizontal dilemma led in 1993 to a power-sharing agreement instead of a democratic government formation. Peacebuilding would have failed had the CPP received only a junior position in the new coalition government. Likewise, the amnesty policy for the Khmer Rouge helped peacebuilding but contradicted democratization. The severe political tensions between the Cambodian opposition and government caused a vertical dilemma. This appears to have led Cambodia's government to 
choose elite-centered over people-centered policy decision-making. But this came at a cost. The elite-centered approach not only limited democratization but also weakened the political legitimacy of the government and policy decisionmaking as shown by the electoral gains of the opposition in the 2013 national elections. The Cambodian government also faced a temporal dilemma. It has been challenging for the government to know how much democratization at which point of time is possible without jeopardizing peacebuilding. Yet, the Cambodian government's prioritization of peacebuilding over democratization came at the cost of a negative long-term effect on democratization as shown by the dissolution of the largest opposition party in 2017.

Cambodia's setback in democratization reveals that it will take a new post-civil war generation of Cambodian political elites to achieve political reconciliation. Currently, a civil war generation dominates Cambodian politics who appears irreconcilable in their political discourses over Cambodia's violent past. Even though FUNCINPEC and CPP seem to have partly reconciled after the 1997 July Crisis, it appears that the fiercest opponents of the CPP have shifted their political support from FUNCINPEC and BLDP to the SRP, HRP, and the CNRP. Especially the CNRP and CPP leadership seem so entrenched in the legacies of Cambodia's violent past that they are unable to reconcile. Although short-lived, the initiative of the government and opposition to develop a culture of dialogue demonstrates that political reconciliation is possible. Cambodia will need more of these initiatives. They may well lead, in the long-run, to the consolidation of liberal multiparty democracy as foreseen in the Paris Peace Accords and the Cambodian constitution.

\section{Acknowledgments}

I appreciate the feedback and critical comments from peer-reviewers and editors at the Asian Journal for Peacebuilding (AJP). They were very helpful in improving this research article.

\section{References}

Ablin, David A., and Hood Marlow, eds. 1990. The Cambodian Agony. 2nd ed. New York: Routledge.

Ashley, David. 1998. Between War and Peace: Cambodia 1991-1998. London: Conciliatory Resources.

Bhagat, Renu. 2015. "Separation of Powers without Checks and Balances in Cambodia." Journal of Alternative Perspectives in the Social Sciences 6 (4): 389-401.

Baliga, Ananth, Turton Shaun, and Mech Dara. 2016. "US Officials Says Military Cooperation at Risk." Phnom Penh Post, July 20.

Baliga, Ananth, and Ben Sokhean. 2018. “Cambodia’s People's Party Sweeps Senate 
Elections." Phnom Penh Post, February 25.

Becker, Elizabeth. 1998. When The War Was Over: Cambodia and the Khmer Rouge Revolution. New York: Public Affairs.

Beresford, Melanie. 2005. "Cambodian in 2004: An Artificial Democratization Process." Asian Survey 45 (1): 134-39.

Cambodian Ministry of Foreign Affairs and International Cooperation. 1997. Crisis in July: A Report on the Insurrection: Its Origin, History and Aftermath. Phnom Penh: Cambodian Ministry of Foreign Affairs and International Cooperation.

CNV (Cambodia New Vision). 2014a. Issue 196. Phnom Penh: Government Publication.

CNV (Cambodia New Vision). 2014b. Issue 200. Phnom Penh: Government Publication.

Cederman, Lars-Erik, Simon Hu, Simon, and Lutz F. Krebs. 2010. "Democratization and Civil War: Empirical Evidence." Journal of Peace Research 47 (3): 377-94.

Chakrya, Khouth Sophak, Charles Parkinson, and Turton Shaun. 2015. "Lawmakers Beaten at National Assembly." Phnom Penh Post, October 27.

Chambers, W. Paul. 2015. “'Neo-Sultanistic Tendencies': The Trajectory of Civil-Military Relations in Cambodia." Asian Security 11 (3): 179-205.

Chhim, Kristina. 2000. Die Revolutionäre Volkspartei Kampuchea von 1979 bis 1989. Frankfurt a. M.: Peter Lang Verlag.

COMFREL (Committee for Free and Fair Elections). 1998. National Assembly Elections 1998: Final Report and Assessment. Phnom Penh: COMFREL.

COMFREL (Committee for Free and Fair Elections). 2002. Commune Council Elections 2002: Final Report and Assessment. Phnom Penh: COMFREL.

COMFREL (Committee for Free and Fair Elections). 2003. National Assembly Elections 2003: Final Report and Assessment. Phnom Penh: COMFREL.

COMFREL (Committee for Free and Fair Elections). 2007. Commune Council Elections 2007: Final Report and Assessment. Phnom Penh: COMFREL.

COMFREL (Committee for Free and Fair Elections). 2008. National Assembly Elections 2008: Final Report and Assessment. Phnom Penh: COMFREL.

COMFREL (Committee for Free and Fair Elections). 2012. Commune Council Elections 2012: Final Report and Assessment. Phnom Penh: COMFREL.

COMFREL (Committee for Free and Fair Elections). 2012. Democracy, Elections, and Reform: Annual Report. Phnom Penh: COMFREL.

COMFREL (Committee for Free and Fair Elections). 2013. Democracy, Elections, and Reform: Annual Report. Phnom Penh: COMFREL.

COMFREL (Committee for Free and Fair Elections). 2014. Democracy, Elections, and Reform: Annual Report. Phnom Penh: COMFREL.

COMFREL (Committee for Free and Fair Elections). 2015 Democracy, Elections, and Reform: Annual Report. Phnom Penh: COMFREL.

COMFREL (Committee for Free and Fair Elections). 2016. Democracy, Elections, and Reform: Annual Report. Phnom Penh: COMFREL.

COMFREL (Committee for Free and Fair Elections). 2017. Democracy, Elections, and Reform: Annual Report. Phnom Penh: COMFREL.

Croissant, Auriel. 2016. Electoral Politics in Cambodia. Historical Trajectories, Current Challenges, and Comparative Perspectives. Singapore: Institute of Southeast Asian Studies, Yusof Ishak Institute.

Croissant, Auriel. 2008. “The Perils and Promises of Democratization through United 
Nations Transitional Authority: Lessons from Cambodia and East Timor." Democratization 15 (3): 649-68.

Dara, Mech. 2015. "Kem Sokha Blasts Hun Sen's Era of Destruction." Cambodia Daily, January 19.

Dara, Mech. 2016. "Bodyguard Unit Ready for 'Color Revolution.” Phnom Penh Post, August 3.

Eang, Mengleng, and Peter Zsombor. 2013. "Kem Sokha Says S-21 Was Vietnamese Conspiracy." Cambodia Daily, May 27.

Fitzpatrick, Michelle. 2011. "Cambodia Tears up the Freedom to Muffle Dissent." Agency France Press, January 30.

Frost, Frank. 1994. "Cambodia: From UNTAC to Royal Government." Southeast Asian Affairs, 79-101.

Halperin, Sandra, and Heath Oliver. 2012. Political Research: Methods and Practical Skills. Oxford: Oxford University Press.

Hazdra, Peter. 1997. Die UN-Friedensoperation in Kambodscha. Vorgeschichte, Konzept, Verlauf, und Kritische Evaluierung des Internationalen Engagements. European University Studies: Peter Lang.

Hughes, Caroline, and Sopheap Real. 2000. Nature and Causes of Conflict Escalation in the Cambodian Election. Phnom Penh: Cambodian Development Resource Institute/ Cambodian Centre for Conflict Resolution.

Hughes, Caroline. 2015. "Understanding the Elections in Cambodia 2013.” Journal of Global Area Based Studies (Special Issue), 1-20.

IBAHRI (International Bar Association's Human Rights Institute). 2015. "Justice Versus Corruption: Challenges to the Independence of the Judiciary in Cambodia." https:// www.ibanet.org/Article/NewDetail.aspx?ArticleUid=fb11e885-5f1d-4c03-9c5586ff42157ae1 (accessed February 18, 2020).

ICG (International Crisis Group). 1998. "Cambodia's Election Turn Sour." Cambodia Report No. 3, Belgium/Brussels. https://www.crisisgroup.org/asia/south-east-asia/ cambodia/cambodias-elections-turn-sour (accessed February 18, 2020).

Jarstad, Anna K. 2008. "Dilemmas of War-to-democracy Transitions: Theories and Concepts." In From War to Democracy: Dilemmas of Peacebuilding, eds. Anna K. Jarstad and Timothy D. Sisk. Cambridge: Cambridge University Press, 15-36.

Kiernan, Ben. 2002. The Pol Pot Regime: Race, Power, and Genocide in Cambodia under the Khmer Rouge, 1975-1979. New Haven, Connecticut: Yale University.

Kijewski, Leonie, and Chakrya Khouth Sophak. 2017. "CPP Big Winner in Local Seat Reallocation." Phnom Penh Post, December 4.

Kuch, Naren. 2015a. "Parties Agree to Code of Conduct for 'Culture of Dialogue."' Cambodia Daily, May 9.

Kuch, Naren. 2015b. "Hun Sen Calls Rainsy a Liar Over Still-Jailed Activist." Cambodia Daily, September 3.

Linton, Suzanne. 2004. Reconciliation in Cambodia. Phnom Penh: Documentation Centre of Cambodia.

Lizee, Pierre P. 2000. Peace, Power, and Resistance in Cambodia: Global Governance and the Failure of International Conflict Resolution. London: MacMillan Press Ltd.

Meas, Sokchea. 2010. "Sam Rainsy files complaint against Hun Sen." Phnom Penh Post, September 26. 
Meas, Sokchea. 2013. "Without Debate, Assembly Passes Heavily Criticized Denial Law." Phnom Penh Post, June 7.

Meas, Sokchea, and Shaun Turton. 2015."Hanoi Slams 'Extremists." Phnom Penh Post, July 2. Mehta, Harish C. 1999. Hun Sen-Strongman of Cambodia. Singapore: Paperback.

Menzel, Jörg. 2016. “Cambodia: From Civil War to a Constitution to Constitutionalism?" In Cambodian Constitutional Law, eds. Hor, Peng, and Kong Phallack, and Jörg Menzel. Phnom Penh: Konrad-Adenauer-Stiftung (KAS), 7-39.

Ngarm, Sot Plai. 2017. Cambodia Reconciliation. A Reflection on Justice Reconciliation Issues and Challenges for the Past 25 Years Post-War Peace and Reconciliation. Siem Reap: Centre for Peace and Conflict Studies.

Narim, Khoun, and Colin Meyn. 2013. "Rainsy, Sokha Draw Large Crowds in Siem Reap." Cambodia Daily, July 25.

Noren-Nilsson, Astrid. 2016. Cambodia's Second Kingdom: Nation, Imagination, and Democracy. New York: Cornell University.

Ou, Virak. 2016. "An Overview and Analysis of the Current Political Situation in Cambodia." Briefing Note, February 3. Phnom Penh: Future Forum Domestic Politics. https:// docs.google.com/a/puc.edu.kh/viewer?a=v\&pid=sites\&srcid=ZGVmYXVsdGRvb WFpbnxvdXZpcmFrfGd4OjQxZWY0ZThjNDc0MDRkMDk (accessed February 18, 2020).

Peou, Sorpong. 1998. "Hun Sen’s Pre-Emptive Coup: Causes and Consequences." Southeast Asian Affairs, 86-102.

Peou, Sorpong. 2014. "The Limits and Potentials of Liberal Peacebuilding for Human Security.” Asian Journal of Peacebuilding 2 (1): 37-60.

Peou, Sorpong. 2017. "Peace through Democracy and Justice? Legacies and Lessons from the Case of Cambodia." Asian Journal of Peacebuilding 5 (1): 89-110.

Reaves, Joseph A. 1988. "Vietnam Reveals Cambodia Death Toll.” The Chicago Tribune, July 1.

Sliwinski, Marek. 1995. Le Genocide Khmer Rouge: Une Analyse Demographique. Paris: L'Harmattan.

Sokhean, Ben, Mech Dara, and Anath Baliga. 2017. “'Death of Democracy”: CNRP Dissolved by Supreme Court Ruling." Phnom Penh Post, November 17.

Springer, Simon. 2010. Cambodia's Neoliberal Order: Violence, Authoritarianism, and the Contestation of Public Space. New York: Routledge.

Sullivan, Michael. 2016. Cambodia Votes: Democracy, Authority and International Support for Elections 1993-2013. Copenhagen/Denmark: Nordic Institute of Asian Studies (NIAS) Press.

SRP (Sam Rainsy Party). 2011. "Resolutions of the Fifth Convention of the Sam Rainsy Party heldin Phnom Penh on September 11, 2011." Phnom Penh: SRP.

Strangio, Sebastian. 2014. Hun Sen's Cambodia. New Haven and London: Yale University.

Un, Kheang. 2009. “The Judicial System and Democratization in Post-Conflict Cambodia.” In Beyond Democracy in Cambodia. Political Reconstruction in a Post-Conflict Society, eds. Joakim Öjendal and Mona Lilja. Copenhagen: Nordic Institute of Asian Studies (NIAS) Press, 70-100.

Un, Kheang. 2005. "Patronage Politics and Hybrid Democracy: Political Change in Cambodia 1993-2003." Asian Perspective 29 (2): 203-30.

Un, Kheang. 2006. "State, Society, and Democratic Consolidation: The Case of Cambodia." 
Pacific Affairs 79 (2): 225-45.

UNHCHR (United Nations High Commissioner for Human Rights). 1998. "Grenade Attack in Phnom Penh 30 March 1997 and Extrajudicial Executions 2-7 July 1997: An Assessment of the Investigations." http://ohchr.demo-kd.com/sites/default/files/ Thematic-reports/Thematic_CMB13051998E1.pdf (accessed February 18, 2020).

Vickery, Michael. 1994. “The Cambodian People's Party: Where Has It Come from, Where Is It Going?” Southeast Asian Affairs, 102-17.

Vickery, Michael. 1997. “Eine Andere Sicht des Putsches.” Südostasien, September 15.

Villa-Vicencio, Charles. 2004. "Reconciliation." In Pieces of the Puzzle: Keywords on Reconciliation and Transitional Justice, eds. Charles Villa-Vicencio and Erik Doxtader. Cape Town, South Africa: Institute for Justice and Reconciliation, 3-10.

Vong, Sokheng. 2011. "SRP Acting Like Pol Pot." Phnom Penh Post, December 29.

Weiß, Raimund. 2004. "Die Dritten Parlamentswahlen in Kambodscha." International Quarterly for Asian Studies 35 (1-2): 47-61.

Willemyns, Alex. 2014a. "Former KPLNF Celebrate the 35th Anniversary." Cambodia Daily, March 6.

Willemyns, Alex. 2014b. "CNRP's Plans in Opposition Break with the Past." Cambodia Daily, August 7.

Wolpe, Howard, and Steve McDonald. 2008. "Democracy and Peacebuilding: Rethinking Conventional Wisdom.” Round Table 97 (394): 137-45.

Raimund Weiß is an Associate Professor of International Relations at the Pannasastra University, Faculty of Social Sciences and International Relations in Phnom Penh, Cambodia, where he also serves as Associate Dean. He is also a Research Fellow with the Cambodian Institute for Cooperation and Peace (CICP), Phnom Penh. He holds a Ph.D. in Political Science from the Leopold-Franzens University Innsbruck, Austria. His research areas of interest are International Relations, Peace and Conflict Studies, and Sustainability. Email: raimundweiss@puc.edu.kh. 